\title{
ANTIBIOTIC RESISTANCE IN SALMONELLA ENTERITIDIS ISOLATED FROM BROILER CARCASSES
}

\author{
Martha Oliveira Cardoso ${ }^{1}$; Aldemir Reginato Ribeiro ${ }^{1}$; Luciana Ruschel dos Santos ${ }^{2 *}$; Fernando Pilotto ${ }^{1}$; \\ Hamilton L.S. de Moraes ${ }^{1}$; Carlos Tadeu Pippi Salle ${ }^{1}$; Silvio Luís da Silveira Rocha ${ }^{1}$; Vladimir Pinheiro do Nascimento ${ }^{1}$ \\ ${ }^{1}$ Centro de Diagnóstico e Pesquisa em Patologia Aviária, Faculdade Veterinária, Universidade Federal do Rio Grande do Sul, \\ Porto Alegre, RS, Brasil; ${ }^{2}$ Faculdade de Agronomia e Medicina Veterinária, Curso de Medicina Veterinária, Universidade de \\ Passo Fundo, Passo Fundo, RS, Brasil
}

Submitted: May 23, 2005; Returned to authors for corrections: January 18, 2006; Approved: May 06, 2005

\section{SHORT COMMUNICATION}

\begin{abstract}
Eighty Salmonella Enteritidis strains isolated from broiler carcasses between May 1995 and April 1996 in the State of Rio Grande do Sul, Brazil, were tested for antibiotic susceptibility using the disk diffusion method. Resistance to colistin, novobiocin, erythromycin and tetracycline was observed in $100 \%$ of the isolates. The strains showed intermediate resistance at different levels to kanamycin (1.25\%), enrofloxacin (3.75\%), neomycin (3.75\%), fosfomycin (20\%), sulphonamides (86.25\%) and nitrofurantoin (90\%). Resistance to ciprofloxacin, norfloxacin, gentamicin, polymyxin B, sulphametrim and sulphazotrim was not found. Since resistance to antibiotics especially those introduced in the last decades, was detected, it is recommended that their use must be based on the results of resistance tests or minimum inhibitory concentration tests.
\end{abstract}

Key words: antibiotic resistance, broiler carcasses, Salmonella Enteritidis

Antibiotics have been successfully used in poultry for different purposes such as growth promotion, prophylaxis, or therapeutics. However, their indiscriminate use caused an increased bacterial resistance, mainly in Salmonella strains (6).

Live animals are the main source of Salmonella in poultry slaughterhouses, and cross contamination of carcasses during processing with Salmonella, including resistant strains, may occur $(5,16)$. Poultry is a common vector for the transmission of Salmonella (10), and resistant Salmonella may be transmitted to humans via the food chain (1).

In Brazil, Salmonella Enteritidis has been one of the most prevalent serovars isolated in human infections (12) as well as in nonhuman sources, which include broiler carcasses (22), foodstuffs, poultry flocks, environment, sewage, water, animal feed, chiller water, other animals, viscera, stools, unknown sources (24), and raw broilers parts (21).
The present study was carried out with eighty isolates of Salmonella enterica subsp. enterica serovar Enteritidis, detected in broiler carcasses slaughtered between May 1995 and April 1996 in the State of Rio Grande do Sul, Brazil. Each strain was unique, i.e., each strain was isolated from a different carcass.

The strains were isolated using the conventional method for detection of Salmonella, recommended by the Brazilian Ministry of Agriculture and Supply (9). Briefly, twenty-five grams of skin and muscle, collected under aseptic conditions, were taken from each broiler carcass and homogenized in 225 $\mathrm{mL}$ of Bufferd Peptone Water (BPW)(Merck AG, Darmstadt, Germany), and incubated at $37^{\circ} \mathrm{C}$ for $24 \mathrm{~h}$ (pre-enrichment). One $\mathrm{mL}$ of the pre-enrichment broth was subcultured into $9 \mathrm{~mL}$ of tetrathionate broth (Merck), and $0.1 \mathrm{~mL}$ into $9.9 \mathrm{~mL}$ of Rappaport-Vassiliadis broth (Merck), and incubated at $36 \pm 1.0^{\circ} \mathrm{C}$,

*Corresponding Author. Mailing address: Campus I, Bairro São José, BR 285, Km 171, Caixa Postal 611. 99001-970, Passo Fundo, RS, Brasil. Fax: (+5554) 3316-8485. E-mail: luruschel@upf.br 
and $41 \pm 0.5^{\circ} \mathrm{C}$ respectively (selective enrichment). After $24 \mathrm{~h}$, the selective enrichment cultures were streaked onto Rambach and Brilliant Green Novobiocin (Merck) agar plates and incubated at $37^{\circ} \mathrm{C}$ for $24 \mathrm{~h}$. Typical colonies were identified by biochemical and serological tests. Complete antigenic characterization and serovar identification was performed by the Laboratory of Enteric Pathogens of the Oswaldo Cruz Institute (IOC-RJ), Rio de Janeiro.

The Salmonella Enteritidis strains were tested for antimicrobial resistance by the disk diffusion method on Mueller-Hinton agar, according to the method recommended by the National Committee for Clinical Laboratory Standards (NCCLS) (19). The following antimicrobial agents were tested: ciprofloxacin $5 \mu \mathrm{g}$, colistin $10 \mu \mathrm{g}$, erythromycin $15 \mu \mathrm{g}$, enrofloxacin $5 \mu \mathrm{g}$, fosfomycin $200 \mu \mathrm{g}$, gentamicin $10 \mu \mathrm{g}$, kanamycin $30 \mu \mathrm{g}$, neomycin $30 \mu \mathrm{g}$, nitrofurantoin $300 \mu \mathrm{g}$, norfloxacin $10 \mu \mathrm{g}$, novobiocin $5 \mu \mathrm{g}$, polymyxin B 300I.U., sulphametrim $25 \mu \mathrm{g}$, sulphonamide $300 \mu \mathrm{g}$, sulphazotrim $25 \mu \mathrm{g}$ and tetracycline $30 \mu \mathrm{g}$.

The results (Table 1) indicated that $100 \%$ of the Salmonella Enteritidis isolates were resistant to colistin, erythromycin, novobiocin and tetracycilne, while showing intermediate resistance, at different levels, to kanamycin (1.25\%), enrofloxacin $(3.75 \%)$, neomycin $(3.75 \%)$, sulphonamides $(86.25 \%)$ and nitrofurantoin (95\%). On the other hand, none of Salmonella Enteritidis strains showed resistance to ciprofloxacin, gentamicin, norfloxacin, polimyxin $\mathrm{B}$, sulphazotrim and sulphametrim.

Table 1. Antimicrobial resistance of 80 Salmonella Enteritidis strains isolated from broiler carcasses.

\begin{tabular}{lcc}
\hline Antimicrobial drug & $\begin{array}{c}\text { Number of } \\
\text { resistant strains }\end{array}$ & $\begin{array}{c}\text { Resistance } \\
(\%)\end{array}$ \\
\hline Ciprofloxacin $5 \mu \mathrm{g}$ & 0 & $0 \%$ \\
Colistin $10 \mu \mathrm{g}$ & 80 & $100 \%$ \\
Erythromycin $15 \mu \mathrm{g}$ & 80 & $100 \%$ \\
Enrofloxacin $5 \mu \mathrm{g}$ & 3 & $3.75 \%$ \\
Fosfomycin 200 $\mu \mathrm{g}$ & 16 & $20 \%$ \\
Gentamicin $10 \mu \mathrm{g}$ & 0 & $0 \%$ \\
Kanamycin 30 $\mu \mathrm{g}$ & 1 & $1.25 \%$ \\
Neomycin 30 $\mu \mathrm{g}$ & 3 & $3.75 \%$ \\
Nitrofurantoin 300 $\mu \mathrm{g}$ & 76 & $95 \%$ \\
Norfloxacin $10 \mu \mathrm{g}$ & 0 & $0 \%$ \\
Novobiocin 5 $\mu \mathrm{g}$ & 80 & $100 \%$ \\
Polimyxin B 300I.U. & 0 & $0 \%$ \\
Suphametrim 25 $\mu \mathrm{g}$ & 0 & $0 \%$ \\
Sulphonamide 300 $\mu \mathrm{g}$ & 69 & $86.25 \%$ \\
Sulphazotrim $25 \mu \mathrm{g}$ & 0 & $0 \%$ \\
Tetracycline 30 $\mu \mathrm{g}$ & 80 & $100 \%$ \\
\hline
\end{tabular}

The results obtained for colistin are in disagreement with those found by Berchieri Jr. et al. (5), who reported an antimicrobial susceptibility of $100 \%$, in Salmonella strains isolated from feces, water, scalding water, chicken carcasses and animal feed in a slaughterhouse in the State of São Paulo, Brazil, and also in disagreement with the results described by Arvanitidou et al. (3), who found only $1.61 \%$ resistance in Salmonella isolated from broiler carcasses in Greece.

Tetracycline had been used as a growth enhancer in food producing animals until 1998, when its use was banned (23). It has also been used as a therapeutic agent, thus the high level of resistance to tetracycline is not surprising (14). The results reported in this study higher than those found by Santos et al. (22) in Brazil (6.25\%), and also by Antunes et al. (2) in Porto, Portugal (36\%). According to Frost et al. (13), ampicillin, streptomycin and tetracycline resistance are plasmid mediated.

The results regarding sulphonamide and nitrofurantoin indicate high resistance to these drugs, which are in agreement with Tassios et al. (26), who worked with Salmonella isolated from animals and food between 1987 and 1993, in Greece, and showed high incidence of resistance to sulphonamide (67.34\%) and nitrofurantoin $(57.82 \%)$

Resistance to enrofloxacin was lower (3.75\%) than the $12.2 \%$ found by Nascimento et al. (18), in Salmonella Enteritidis isolated from clinical and environmental poultry samples in Southern Brazil, and lower than the 50\% described by Antunes et al. (2), in Salmonella isolated from poultry products in Porto, Portugal. Resistance to norfloxacin or ciprofloxacin was not detected.

Currently, some authors have observed an increase in quinolone resistance in Salmonella (17). This is a worrying finding, because quinolone resistance is chromosomally mediated thus allowing an increase of Salmonella quinoloneresistant in humans or animals (20). In Germany, the incidence of quinolone resistance between 1986 and 1998 in Salmonellae isolated from cattle, poultry, and pigs, increased in the years following the licensing of this drug (15).

Our findings regarding kanamycin resistance $(1.25 \%)$ are similar to the $1.2 \%$ found by Nascimento et al. (18) in Salmonella Enteritidis isolated from poultry samples in Southern Brazil, and also to the $2.8 \%$ found by Carramiñana et al. (11) in Salmonella Enteritidis isolated from a poultry slaughterhouse in Spain, but lower than the $12 \%$ found by Blackburn et al. (7) in Salmonellae isolated from food producing animals in the United States.

All isolates of Salmonella Enteritidis were susceptible to gentamicin but resistant to erythromycin, results which were similar to those obtained by Blackburn et al. (7). After many years of use, gentamicin remains effective against Salmonella $(2,25)$. Sulphazotrim and polymyxin B were effective against all Salmonella Enteritidis isolates, being in agreement with findings of Santos et al. (22), but in disagreement with those of Berchieri and Paulillo (4), who obtained $100 \%$ of sulphazotrim resistance in Salmonella strains isolated from feed meals. 
According Blackburn et al. (7), the prevalence of antibiotics resistance is quite high in Salmonella strains from different places of the United States, also when comparing results from different animal species (chickens, turkey, cattle and swine). The different levels of resistance are attributed to varying degrees of exposure to drug pressures.

The differences between the results of the present paper and those of other researchers, may be explained when several factors, such as differences in origin, time period of collection and sampling procedure (10).

The development of antimicrobial resistance in zoonotic bacteria (e.g.: Salmonella) constitutes a public health risk, as it may potentially affect the efficacy of drug treatment in humans (1). Therefore, the levels of antibacterial resistance found in this study emphasize that antibiotics must be used judiciously, based on previous resistance tests and on the determination of appropriate doses by minimal inhibitory concentration (MIC). These goals can be achieved by the constant training of medical professionals regarding general recommendations for the use of these drugs, in addition to a deeper knowledge of their pharmacokinetics, and especially fully knowledge about the microbiology of Salmonella.

\section{ACKNOWLEDGEMENTS}

The authors wish to acknowledge CDPA-UFRGS 's staff for the technical assistance, Dr. Lenita Moura for proof reading this paper, and CAPES for the financial support.

\section{RESUMO}

\section{Resistência antimicrobiana em Salmonella Enteritidis isoladas de carcaças de frango}

Oitenta amostras de Salmonella Enteritidis isoladas de carcaças de frango no período entre maio de 1995 a abril de 1996 no Estado do Rio Grande do Sul, Brasil foram testados para susceptibilidade antimicrobiana pelo método de antibiograma. $\mathrm{O}$ antibiograma das amostras apresentou $100 \%$ de resistência a colistina, novobiocina, eritromicina e tetraciclina. Tiveram resistência em diferentes níveis a canamicina $(1,25 \%)$, enrofloxacina $(3,75 \%)$, neomicina $(3,75 \%)$, fosfomicina $(20 \%)$, sulfonamida $(86,25 \%)$ e nitrofurantoína $(90 \%)$ e por outro lado não apresentaram resistência a ciprofloxacina, norfloxacina, gentamicina, polimixina B, sulfametrim e sulfazotrim. A constatação de resistência a antibióticos, inclusive àqueles introduzidos na última década, enfatiza a necessidade de uso responsável de antibióticos, e com base em antibiograma ou concentração inibitória mínima.

Palavras-chaves: carcaças de frango, resistência antimicrobiana, Salmonella Enteritidis

\section{REFERENCES}

1. Aarestrup, F.M. Association between the consumption of antimicrobial agents in animal husbandry and the occurrence of resistant bacteria among food animals. Int. J. Antimicrob. Agents, 12, 279-285, 1999.

2. Antunes, P.; Réu, C.; Souza, J.C.; Peixe, L., Pestana. Incidence of Salmonella from poultry products and their susceptibility to antimicrobial agents. Int. J. Food Microbiol., 82, 97-103, 2003.

3. Arvanitidou, M.; Tsakris, A.; Sofianou, D.; Katsouyannopoulos, V. Antimicrobial resistance and R-factor transfer of Salmonellae isolated from chicken carcasses in Greek hospitals. Int. J. Food Microbiol., 40, 197-201, 1998.

4. Berchieri Jr., A.; Paulillo, A.C. Sensibilidade a Antimicrobianos por Salmonella Isolados de Farinhas de Origem Animal Utilizados no Preparo de Rações. Rev. Microbiol., 16(1), 56-60, 1985.

5. Berchieri Jr., A.; Paulillo, A.C.; Fernandes, S.A.; Pessoa, G.V.A.; Rossi Jr., O.D.; Irino, K.; Ávila, F.A.; Calzada, C.T. Salmonella em um Abatedouro Avícola. Ars Vet., 3(1), 81-87, 1987.

6. Berchieri Jr., A.; Adachi, S.Y.; Calzada, C.T.; Paulillo, A.C.; SchokenIturrino, R.P.; Tavechio, A.T. Farinha de Carne como Fonte de Salmonella em Granja avícola. Pesq. Vet. Bras., 9(1/2), 9-12, 1989.

7. Blackburn, B.O.; Schlater, L.K.; Swanson, M.R. Antibiotic resistance of members of the genus Salmonella isolated from chickens, turkeys, cattle, and swine in the United States during October 1981 through September 1982. Am. J. Vet. Res., 45(6), 1245-1249, 1993.

8. Bokanyi Jr., R.P.; Stephens, J.F.; Foster, D.N. Isolation and Characterization of Salmonella from Broiler Carcasses or Parts. Poult. Sci., 69, 592-598, 1990.

9. Brasil. Ministério da Agricultura e do Abastecimento / Secretaria de Defesa Agropecuária. Método Analítico de Carcaças de Aves e Pesquisa de Salmonella. Diário Oficial da União. Brasília, Portaria SDS no 8, de 23 de janeiro de 1995. p.1182-1184 de 27 de janeiro de 1995. Seção I.

10. Bryan, F.L.; Dole, M.P. Health risks and consequences of Salmonella and Campylobacter jejuni in raw poultry. J. Food Protec., 58, 326344, 1995.

11. Carramiñana, J.J.; Rota, C.; Agustín, I.; Herrera, A. High prevalence of multiple resistance to antibiotics in Salmonella serovars isolated from a poultry slaughterhouse in Spain. Vet. Microbiol., 104, 133139, 2004,

12. Castro, F.A.; Santos, V.R.; Martins, C.H.G.; Fernandez, S.A.; Zaia, J.E.; Martinez, R. Prevalence and Antimicrobial Susceptibility of Salmonella Serotypes in Patients from Ribeirão Preto, São Paulo, Brazil, between 1985 and 1999. Braz. J. Infec. Dis., 6(5), 244-251, 2002.

13. Frost, J.A.; Ward, L.R.; Rowe, B. Acquisition of a drug resistance plasmid converts Salmonella Enteritidis phage type 4 to phage type 24. Epidemiol. Infect., 103(2), 243-248, 1989.

14. Irwin, R.J.; McEwen, A.; Clarke, R.C.; Meek, A.H. The Prevalence of Verocytotoxin-Producing Escherichia coli and Antimicrobial Resistance Patterns of Nonverocytotoxin-Producing Escherichia coli and Salmonella in Ontario Broiler Chickens. Can. J. Vet. Res., 53, 411-418, 1989.

15. Malorny, B.; Schroeter, A.; Helmuth, R. Incidence of Quinolone Over the Period of 1986 to 1998 in Veterinary Salmonella Isolated from Germany. Antimicrob. Agents Chemother, 43(9), 2278-2282, 1999.

16. Mandal, B.K. Salmonella infection and food hygiene. Curr. Opin. Infect. Dis., 4, 67-73, 1991.

17. Molbak, K.; Gerner-Smidt, P.; Wegerner, H.C. Increasing Quinolone Resistance in Salmonella Enterica Serotype Enteritidis. Emerging Infect. Dis., 8(5), 514-515, 2002. 
18. Nascimento, V.P.; Kellermann, A.; Ribeiro, A.R.; Santos, L.R.; Marks, F.; Camargo, L.; Bosoi, A. Antimicrobial Resistance Profile of Salmonella Enteritidis Isolated from Clinical and Environmental Poultry Samples, 1999-2001. XVII Congresso Latinoamericano de Microbiologia, Buenos Aires - Argentina, 2004.

19. National Committtee for Clinical Laboratory Standards - NCCLS Performance Standards for Antimicrobial Susceptibility Testing; $11^{\text {th }}$ Information Supplement. Approved Standard M2-A7 and M7-A5. Wayne, PA, U.S.A., 2001.

20. Piddock, L.J.V. Fluoroquinolone resistance in Salmonella serovars isolated from human and food animals. FEMS Microbiol. Rev., 26 3-16, 2002.

21. Ribeiro, A.R.; Nascimento, V.P.; Cardoso, M.O.; Santos, L.R.; Rocha, S.L.S. Utilization of Immunomagnetic Separation for Detection of Salmonella in Raw Broiler Parts. Braz. J. Microbiol., 33(4), 339$341,2002$.
22. Santos, S.M.S.; Berchieri Jr., A.; Fernandes, S.A.; Tavechio, A.T.; Amaral, L.A. Salmonella em carcaças de frango congeladas. Pes. Vet. Bras., 20(1), 39-42, 2000.

23. Silva, E.N., Duarte, A. Salmonella Enteritidis em Aves: Retrospectiva no Brasil. Rev. Bras. Cienc. Avic., 4(2), 85-100, 2002.

24. Tavechio, A.T.; Ghilardi, A.C.R.; Peresi, J.T.M.; Fuzihara, T.O.; Yonamine, E.K.; Jakabi, M.; Fernandez, S.A. Salmonella Serotypes Isolated from Nonhuman Sources in São Paulo, Brazil, from 1996 through 2000. J. Food Protec., 65(6), 1041-1044, 2002.

25. Tollefson, L.; Angulo, F.J.; Fedorka-Cray, P.J. National Surveillance for Antibiotic Resistance in Zoonotic Enteric Pathogens. Vet. Clin. North Am. Food Animal Pract., 14 (1), 141-150, 1998.

26. Tassios, P.T.; Markogiannakis, A.; Vatapoulos, A.C.; Katsanikou, E.; Velonakis, E.N.; Korea-Kremastinou, J.; Legarkis, N.J. Molecular Epidemiology of Antibiotic Resistance of Salmonella enteritidis during a 7-year Period in Greece. J. Clin. Microbiol., 35(6), 1316-1321, 1997. 